Bartın Üniversitesi

Eğitim Fakültesi Dergisi

Cilt 5, Sayı 3, s.669-689, Ekim 2016

BARTIN - TÜRKIYE

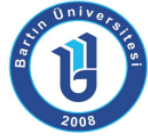

ISSN: 1308-7177
Bartin University

Journal of Faculty of Education

Volume 5, Issue3, p. 669-689, October 2016

BARTIN - TURKEY

\title{
Okul Öncesi Çocuklarının Bilim İnsanı Kavramına Yönelik Algıları
}

Hakan Şevki AYVACI, Doç. Dr., Karadeniz Teknik Üniversitesi Fatih Eğitim Fakültesi, hsayvaci@gmail.com

Alper ATIKK, Karadeniz Teknik Üniversitesi Fatih Eğitim Fakültesi, alperatik_84@hotmail.com

Mustafa ÜREY, Yrd. Doç. Dr., Karadeniz Teknik Üniversitesi Fatih Eğitim Fakültesi, murey01@gmail.com

Özet: Bu çalışma okul öncesi dönemde bulunan çocukların bilim insanı kavramına yönelik algılarını belirlemek amacıyla yapılmıştır. Araştırmanın katılımcılarını Trabzon ili Beşikdüzü ilçesinden rastgele seçilen iki anaokulunda öğrenim gören 48-72 ay aralığındaki 68 çocuk oluşturmaktadır. Veriler, Chambers'in (1983) "Bir Bilim İnsanı Çiz Testi" ve derinlemesine mülakat tekniği ile toplanmıştır. Elde edilen veriler, araştırma üçgenlemesi yöntemi ile uzman görüşüne başvurularak temalar oluşturulmuş ve bu temalara göre analiz edilmiştir. Analiz sonuçlarına göre okul öncesi çocuklarının çoğu bilim insanını erkek, laboratuvarda çalışan, araştırmalar yapan ve karışımlar oluşturan, laboratuvar malzemeleri ve bilgisayar kullanan, önlük giyen ve gözlük takan kişiler olarak belirtmişlerdir. Bu sonuçlar doğrultusunda, çocuklara bilim insanı ile ilgili daha gerçekçi algılar oluşturmak amacıyla bilim insanı konulu etkinliklere daha fazla yer verilmesi önerilmiştir.

Anahtar Kelimeler: Bilim, Bilim İnsanı, Okul Öncesi, Çocuk, Algı

\section{The Perceptions of Preschool Children on the Concept of Scientist}

\begin{abstract}
This study was conducted to determine the perception of the concept of scientist for preschool children. The participants of this study consist of 68 children aged between 48-72 months. The children are randomly selected from the prescool in Beşikdüzü which is a town of Trabzon. Data of the study was collected through "Draw A Scientist Test" (Chambers, 1983) and in-depth interview. To evaluate the collected data, themes were created by using the triangulation method and the data were analyzed. According to the results of the analysis, most of the preschool children define the scientists as male and working in a laboratory, conducting researches, preparing mixture, using laboratory stuff, using a computer, wearing a laboratory coat and glass. Based on these results, it was proposed that there should be more activities which are about the scientist to let the children create more realistic perceptions.
\end{abstract}

Key Words: Science, Scientest, Preschool, Child, Perception 


\section{GíRiş}

Bilimsel uygulamalara her alanda ihtiyaç duyulduğu ve bu uygulamalardan ortaya çıkan ürünlerin kullanıldığı günümüz dünyasında bilimin önemi tartışımaz bir gerçektir. Her alanda kullanılmasına rağmen bilimi tanımlamak insanlara oldukça zor gelmektedir. Einstein; "Bilim her türlü düzenden yoksun duyu verileri ile düzenli mantıksal düşünme arasında uygunluk sağlama çabası" olduğunu söylerken, Russell; "Bilim, gözlem ve gözleme dayalı akıl yürütme yoluyla önce dünyaya ilişkin olguları, sonra bu olguları birbirine bağlayan yasaları bulma çabası" olarak tanımlamaktadır (Doğan Bora, Arslan ve Çakıroğlu, 2006). Yıldırım (2005) ise bilimi; "Doğruyu bulma, olup bitenleri açıklama arayışı sürecinde ussal olduğu kadar imgesel ve duygusal tüm yetilerimizi içeren bir etkinliktir." diye tanımlamıştır. Bilim kavramının bu denli farklı şekillerde tanımlanmasının sebebi olarak; bilimin sürekli değişen, yenilenen, gelişen, çok yönlü ve karmaşık olması; incelediği olaylar, olgular ve kullandığı yöntemler yönünden sınırları tam olarak belirlenememesi gösterilebilmektedir (Doğan Bora, Arslan ve Çakıroğlu, 2006). Çocukların gözüyle bilimi anlayabilmek için bilim yapıcıların yani bilim insanlarının nasıl algılandığını ortaya koymak önemlidir.

Bilim, eleştirel ve mantıksal düşünmeyi, merak etmeyi, şüpheyi vurgulayan bir çalışma olarak düşünüldüğünde; bilim insanı da bu çalışmayı en iyi şekilde başlatan, yürüten ve sonlandıran kişi olarak nitelendirilebilir (Özoğlu, 1994). Korkmaz'a (2004) göre bilim insanı mantıksal ve evrensel düşündüğü gibi aynı zamanda önyargılardan uzak, objektif ve eleştiricidir. Geniş bir hayal ve yorumlama gücüne sahip olan bilim insanı yaptığı çalışmaları bilimsel temellere dayandıır ve bilimsel kurallara uygun çalışır.

Dünyada ve ülkemizde bilim ve bilim insanı kavramlarının nasıl algılandığının belirlenmesi amacıyla yapılan çeşitli çalışmalar (Tatlı, Önen, Akgül ve Gürdal, 2013; Aslan, Yalçın ve Taşar, 2009; Barman, 1997; Chambers, 1983; Çermik, 2013; Doğan Bora ve diğerleri, 2006; Güler ve Akman, 2006; Kaya ve diğerleri, 2008; Kılıç, 2010; Özgelen, 2012; Özsoy ve Ahi, 2014) bulunmaktadır. Yapılan bu çalışmalarda bilim insanı, daha çok beyaz önlük giyen, laboratuvarda çalışan, çoğunlukla erkek, orta yaşlı, gözlüklü, dağınık saçlı marjinal tipler olarak tanımlanmaktadır. Yapılan bu çalışmaların ortak sonucu olarak, bilim ve bilim insanlarına yönelik algıların okul öncesi dönemlerden itibaren oluşmaya başladığı da ifade edilmektedir. Çocuklar küçük yaşlarda çevrelerini tanıyıp anlamlandırmaya çalışırlarken bilim ve bilim insanı kavramlarıyla karşılaşmakta ve belli kalıptaki yargılarını bu dönemde oluşturmaktadırlar (Çermik, 2013). Özellikle okul öncesi çocukları için bilginin yapılandırılma süreci ve bilim çok anlaşıır bir durum değildir. Bu dönem çocukları bilim kavramını ancak ve ancak rol modeller üzerinden şekillendirebilmekte ve bir bilim algısı oluşturma sürecine girmektedirler. Bu durumda okul öncesi çocukları için bilim kavramını nasıl algıladıklarını ortaya koymak ancak bilimin temsilcileri olan bilim insanlarını nasıl algıladıklarıyla anlaşılabilir. Çocukların deneyimleri sonucu zihinlerinde oluşturdukları bilim insanı algısı, güncel yaşamlarında karşılaştıkları problemlere nasıl çözüm üretebilecekleri konusunda oldukça etkilidir (Özsoy ve Ahi, 2014). Ayrıca gelecekte bilimsel çalışmalara devam edip etmeyecekleri de bilim insanları üzerinde oluşturdukları olumlu ya da olumsuz algıların bir sonucu olarak şekillenecektir. Çocukların bilim insanları ve bilim hakkında oluşturacakları olumsuz algılar, onların bilimsel etkinliklere karşı olan düşüncelerinin ve tutumlarının şekillenmesinde önemli rol oynamaktadır. Oluşması muhtemel bu olumsuz düşünceler öğrencilerin gelecekteki okul hayatlarına da yansıyarak, kişinin bilimden uzaklaşmasına, ilgili dersleri sevmemesine ve bu konuda başarısız olmasına neden olabilmektedir (Güler ve Akman, 2006). Bu nedenle de bu dönemde bilime ve bilim insanına karşı olumlu tutum geliştirilmesinin sağlanması, bilgi çağına ayak uydurabilen bireylerin yetiştirilebilmesi için çok önemli bir dönüm noktasıdır. Ayrıca okul öncesi çocuklarının bilim insanına yönelik algıları, ilkokul düzeyindeki sınıf öğretmenlerine ve program 
geliştiricilerine ışı tutacaktır. Bu noktadan hareketle, erken yaşlardan itibaren öğrencilerin bilim ve bilim insanı hakkındaki algılarının araştırılması, mevcut durumun belirlenmesi ve ayrıca gerekli önlemlerin zaman kaybetmeden alınması büyük önem taşımaktadır (Küçük ve Bağ, 2011).

Bilim insanı hakkındaki algılar erken yaşlarda oluşmaya başladığından, okul öncesi çocuklarının bilim insanı algıları üzerinde daha fazla çalışma yapmaya ihtiyaç vardır. Ülkemizde okul öncesi dönem çocuklarının bilim ve bilim insanı üzerindeki algılarına yönelik çalışmalar incelendiğinde sınırlı sayıda çalışmaya (Güler ve Akman, 2006) rastlanmıştır. Yapılan çalışma ile hem bu eksikliğin giderilmesi hem de değişen dünyada çocukların bilim insanına yönelik algıları tespit edilmeye çalışılmıştır.

\section{YÖNTEM}

\subsection{Araştırmanın Modeli}

Bu araştırma, okul öncesi çocuklarının bilim insanı algılarının ortaya çıkarılması amacıyla nitel olarak desenlenmiş ve araştırmada özel durum yöntemi kullanılmıştır. Creswell (2002) nitel araştırmaların "bir durumu tasvir etme, analiz etme ve bir grup ya da kişilerin algı, davranış ve inançlarını yorumlama" konusunda derinlemesine bilgi sağladığını belirtmektedir (s.481). Betimsel nitelikte olan bu çalışmada da araştırmanın problemi konusunda derinlemesine ayrıntılı bir şekilde araştırma imkânı sunan özel durum yöntemi kullanılmıştır. Özel durum yöntemi ile özel bir durum, kişi, grup ya da olay üzerine yoğunlaşılarak, çalışma grubunu oluşturan katılımcıların kendi öznel deneyimleriyle oluşturduğu yaşam dünyalarına erişilmeye çalışılır (Çepni, 2010; Ekiz, 2009). Yapılan çalışmada okul öncesi öğrencilerinin bilim insanına yönelik algıları çizimler yoluyla alınmış ve katılımcıların kendi deneyimleri ile oluşturduğu önyargısız algıları ortaya konmaya çalışılımıştır.

\section{2. Çalışma Grubu}

Araştırmanın katılımcılarını Trabzon ili Beşikdüzü ilçesinden rastgele seçilen iki anaokulunda öğrenim gören $48-72$ ay aralığındaki 68 çocuk oluşturmaktadır. Uygulama yapılmadan önce okul idarelerinden izin alınarak gerçekleştirilen bu çalışmada, araştırma etiği gereği katılımcıların isimleri kullanılmamıştır. Ç1, Ç2, Ç3,...Ç68 kodlarıyla isimlendirilen katılımcılara ait demografik bilgiler Tablo 1'de sunulmuştur.

Tablo 1

Araştırmaya Katılan Çocuklara Ait Demografik Bilgiler

\begin{tabular}{lcccc}
\hline & $\mathbf{4}$ Yaş & $\mathbf{5}$ yaş & $\mathbf{6}$ Yaş & Toplam \\
\hline Erkek & 9 & 21 & 11 & 41 \\
Kız & 8 & 12 & 7 & 27 \\
Toplam & 17 & 33 & 18 & 68 \\
\hline
\end{tabular}

Tablo 1'de görüldüğü gibi araştırmaya katılan 68 çocuktan 41'i erkek, 27'si kızdır. Erkeklerden 9'u 4 yaşında, 21'i 5 yaşında ve 11'i de 6 yaşındadır. Kız çocuklarından 8'i 4 yaşında, 12 'si 5 yaşında ve 7'si de 6 yaşındadır.

\subsection{Veri Toplama Aracı}

Çocukların bilim insanı kavramına yönelik algılarını ortaya çıkarmak amacıyla veri toplama aracı olarak Chambers'in (1983) 'Bir Bilim insanı Çiz Testi' kullanılarak derinlemesine mülakat tekniği uygulanmıştır. Resimler, bireyi kelimelerle sınırlamadan bireyde gizli kalmış bilgi ve inanışların ortaya çıkarılmasında etkili bir araçtır. Resimlerle ilgili karşılaşılabilecek en büyük zorluk resimlerin yorumlanmasıdır (Çepni, 2008). Yapılan çalışmada bu eksikliği giderebilmek ve resimlerden elde edilen verilerin güvenilirliğini artırabilmek için derinlemesine 
mülakat tekniğine de başvurulmuştur. Nitel yöntemde özel bir yeri olan derinlemesine mülakat en güçlü veri toplama tekniklerinden biridir. Bu teknik, araştırılan konunun tüm boyutlarını kapsamaktadır ve araştırma hakkında sorulan sorulara detaylı cevapların alınmasını sağlamaktadır. Ayrıca birebir görüşme yapılan kişinin duygu, düşünce, bilgi, tecrübe ve gözlemlerine ulaşılarak veri toplanmasına da imkân vermektedir (Tekin, 2012). McCracken'a (1988) göre derinlemesine mülakat tekniği, görüşülen kişilere kendilerini birinci elden ifade edebilme imkânı verirken, araştırma yapan kişiye de görüştüğü kişilerin bakış açılarını, içinde bulundukları durumlara ait duygu, düşünce ve tecrübelerini kendi ifadeleriyle anlama imkânı sunar. Johnson (2002) derinlemesine mülakattaki derin kelimesini, mülakat yapılan kişinin gerçek hayatta yaşadıklarının bütün yönleriyle anlaşılmaya çalışılması şeklinde açıklamıştır. Araştırmacı çalıştığı konu ile ilgili olarak görüşme yaptığı kişi ile aynı gruba dahil olarak veriler elde edilmeye çalışılır. Bilinmeyen konularda bilgi almak ya da bilgilerin doğruluğunu kontrol etmek için derinlemesine görüşme tekniği kullanılabilmektedir. Bu bağlamda, kendi doğallığı içerisinde şekillenmesi, esnek olması ve belli bir konuda derinlemesine bilgi sahibi olmayı sağlaması açısından bu çalışmada derinlemesine mülakat yöntemi tercih edilmiştir.

\subsection{Veri Toplama Süreci}

Yapılan testte çocuklardan kendilerine verilen boş bir kağıt üzerine bilimsel araştırma yapan birer bilim insanı resmetmeleri ve yaptıkları resimleri açıklamaları istenmiştir (Küçük ve Bağ, 2011). Bu süreçte çocuklara, yapacakları resimlerde kullanmak üzere kullanacakları boya kalemi seçiminde herhangi bir sınırlama getirilmemiştir ve çocuklara neler çizecekleri konusunda bir yönlendirmede bulunulmamıştır. Çocuklar resimlerini 15-20 dakikalık bir sürede tamamlamış ve onlara yapmış oldukları resimler konusunda ne, neden, niçin gibi sorular sorularak resimler anlamlandırılmaya çalışılmıştır. Yapılan sorgulamalar sonrasında elde edilen veriler not edilerek resimlerin analizine geçilmiştir. Bu çalışmada, resim yeteneği olmayan ve ne yaptığı gerek resminden gerekse mülakatlardan anlaşılamayan çocukların verileri değerlendirme dışı tutulmuştur.

\subsection{Verilerin Analizi}

Okul öncesi dönemdeki çocukların bilim insanı hakkındaki algılarını ortaya çıkarmak amacıyla onlara yaptırılan resimlerin analizinde, araştırma üçgenlemesi kullanılarak yapılan resimlerden elde edilen ortak kod ve temalar belirlenmeye çalışılmıştır. Merriam (1998) çalışmanın geçerliliğini artırmak için verilerin bir uzmana inceletilmesi ve katılımcı onayının alınması gerektiğini ileri sürmektedir. Bu kapsamda, kod havuzunda yer alan kodlar ve bu kodların bağlı olduğu temalar, alan uzmanı 2 öğretim üyesine onaylatılarak uzman incelemesi gerçekleştirilmiştir. Yapılan çalışma sonrasında aşağıdaki temalara ulaşılmış ve temalar dikkate alınarak yapılan analiz sonuçları temalara ait kodlarla birlikte bulgular halinde sergilenmiştir.

1. Bilim insanının cinsiyeti

2. Bilim insanının çalışma şekli

3. Bilim insanının çalışma ortamı

4. Bilim insanının fiziksel özellikleri

5. Bilim insanının kullandığı araç gereçler

6. Bilim insanının mesleki özellikleri

\section{BULGULAR}

Okul öncesi çocuklarının bilim insanı kavramına yönelik sahip oldukları algıları ortaya çıkarmak amacıyla yürütülen bu çalışmada, Chambers'in (1983) 'Bir Bilim Insanı Çiz Testi' 
kullanılarak yapılan derinlemesine mülakattan elde edilen bulgular aşağıda tablolar halinde sunulmuştur.

\subsection{Okul Öncesi Çocuklarının Bilim İnsanının Cinsiyeti Hakkındaki Algıları}

Araştırmanın bu bölümünde çocukların yaptıkları resimlerdeki bilim insanlarının cinsiyetleri ele alınmıştır. Yapılan resimlere göre çocukların algılarındaki bilim insanlarının cinsiyetleri ile ilgili veriler Tablo 2'de sunulmuştur.

Tablo 2

Çocukların Zihinlerindeki Bilim Insanının Cinsiyeti

\begin{tabular}{ccc}
\hline Cinsiyet & f & $\%$ \\
\hline Erkek & 45 & 66,17 \\
KIz & 15 & 22,05 \\
Her ikisi & 8 & 11,76 \\
\hline
\end{tabular}

Tablo 2'ye göre çocukların \%66,17'si bilim insanını erkek, \%22,05'i ise bilim insanını kadın olarak resmetmiştir. Çocukların $\% 11,76$ 'sı ise resimlerinde farklı cinsiyette birden fazla bilim insanı yaparak bilim insanlarının hem kadın hem de erkek olabileceğini belirtmişlerdir. Bilim insanlarının cinsiyetleri konusunda Ç6, yaptığı resimdeki bilim insanı modelini: "...bilim adamları erkektir..." şeklinde açıklamıştır. Ç28 ise resmindeki bilim insanı modelini: "...benim çizdiğim bilim adamı kız..." şeklinde belirtmiştir. Ç26 ise bilim insanı modelini: "...erkek bilim insanı da olur kadın da olur..." şeklinde ifade etmiş̧ir. Çocukların açıklamalarına yönelik yaptıkları resimler Şekil 1, Şekil 2 ve Şekil 3'te sunulmuştur.

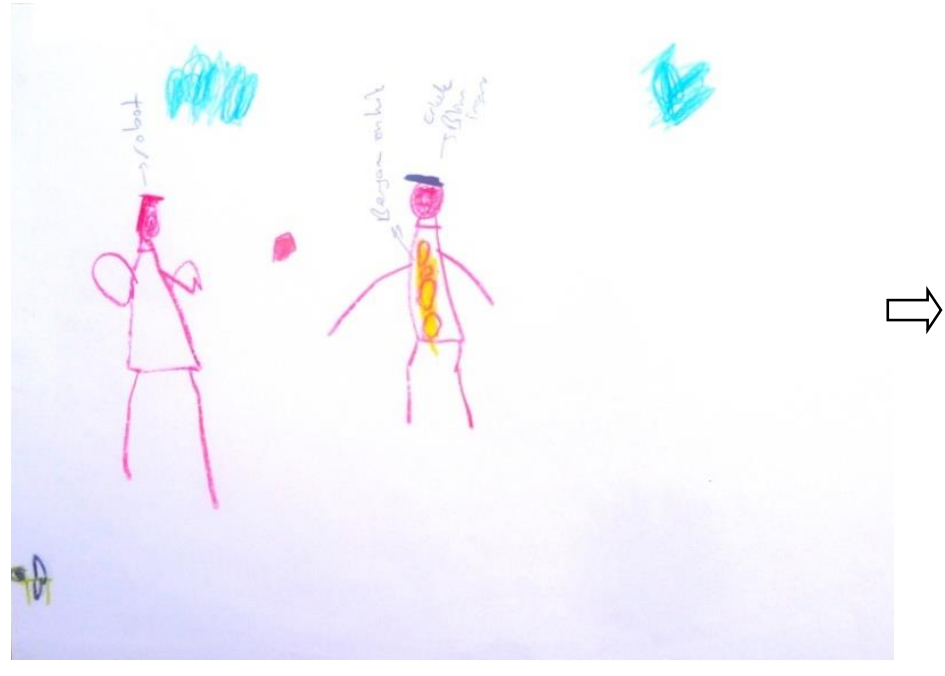

Şekil 1. Ç6 kodlu çocuğun yaptığı bilim insanı konulu
Ç6 kodlu çocuğun bilim insanı kavramına yönelik algısını belirlemek için ona yaptırılan resimde büyük düğmeli beyaz önlük giyen, kısa saçlı, erkek bir bilim insanı ve robot bulunmaktadır. Resimde her hangi bir mekân belirlenmezken, resimde doğa unsurlarından olan bulutlar bulunmaktadır. Ç6'ya göre bu bilim insanı robot yapmaktadır. resim 


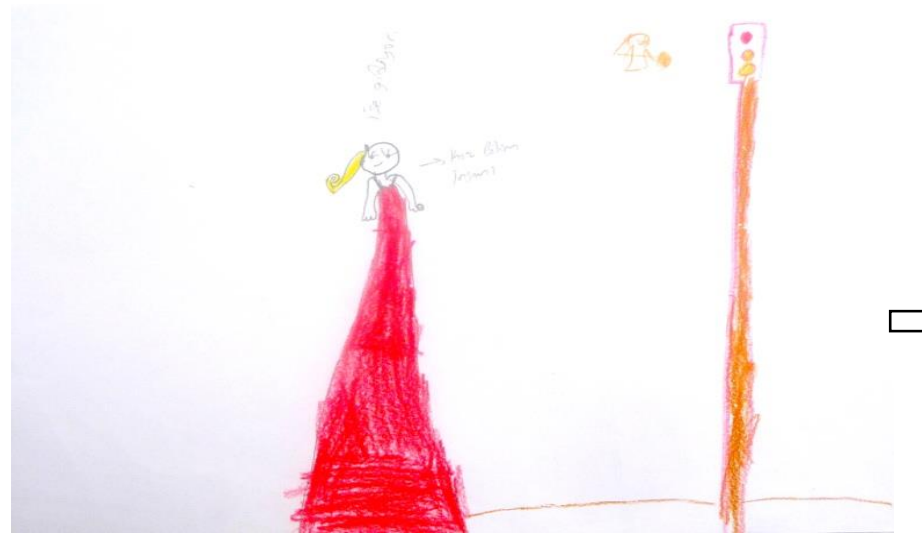

Şekil 2. Ç28 kodlu çocuğun yaptığı bilim insanı konulu resim
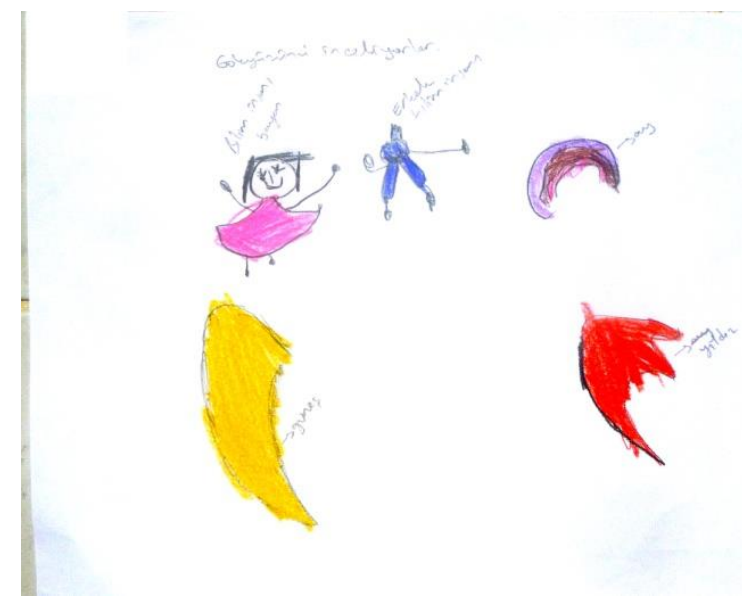

Şekil 3. Ç26 kodlu çocuğun yaptığı bilim insanı konulu resim
Ç25 kodlu çocuğun bilim insanı kavramına yönelik algısını belirlemek için ona yaptırılan resimde kırmızı elbise giyen, sarı ve uzun saçlı kadın bir bilim insanı bulunmaktadır. Mekân olarak dış ortam çizilmiş̧ir. Ayrıca resimde trafik ışığı bulunmaktadır. Ç28'e göre bu bilim insanı işe gitmektedir.

Ç26 kodlu çocuğun bilim insanı kavramına yönelik algısını belirlemek için ona yaptırılan resimde uzun saçlı kadın ve kısa ve az saçlı erkek bilim insanı bulunmaktadır. Ayrıca resimde astronomik öğelerden güneşi ay ve yıldız bulunmaktadır. Ç26'ya göre bu bilim insanları gökyüzünü incelemektedirler.

\subsection{Okul Öncesi Çocuklarının, Bilim İnsanının Çalışma Şekline ilişskin Algıları}

Araştırmanın bu bölümünde çocukların yaptıkları resimlerdeki bilim insanlarının çalışma şekilleri ele alınmıştır. Yapılan resimlere göre çocukların zihinlerindeki bilim insanının çalışma şekilleri ile ilgili veriler Tablo 3 'te sunulmuştur.

Tablo 3

Çocukların Zihinlerindeki Bilim Insanının Çalışma Şekli

\begin{tabular}{ccc}
\hline Çalışma Şekli & $\mathbf{f}$ & $\%$ \\
\hline Bireysel & 38 & 55,8 \\
Grup & 13 & 19,1 \\
\hline
\end{tabular}

Tablo 3'e göre çocukların \%55,8'i resimlerinde bilim insanını bireysel çalışır halde yaparken, $\% 19,1^{\prime} i$ ise grup olarak çalışır halde yapmıştır. Bilim insanlarının çalışma şekilleri konusunda Ç61 yaptığı resimdeki bilim insanının çalışma şeklini: "...bu yandakiler bilim insanının yardımcısı ama onlar da bilim insanı ve beraber çalışıyorlar...." ve Ç20: "...bu bilim insanı tek başına çalışıyor çünkü gizli olması gerek..." şeklinde ifade etmiştir. Çocukların açıklamalarına yönelik yaptıkları resimler Şekil 4 ve Şekil 5 'te sunulmuştur. 


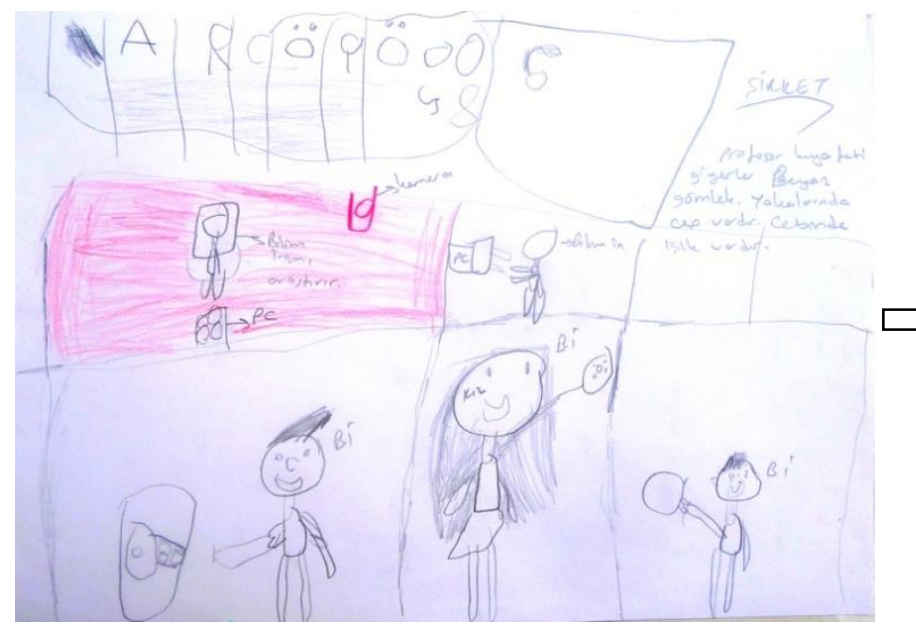

Şekil 4. Ç61 kodlu çocuğun yaptığı bilim insanı konulu resim

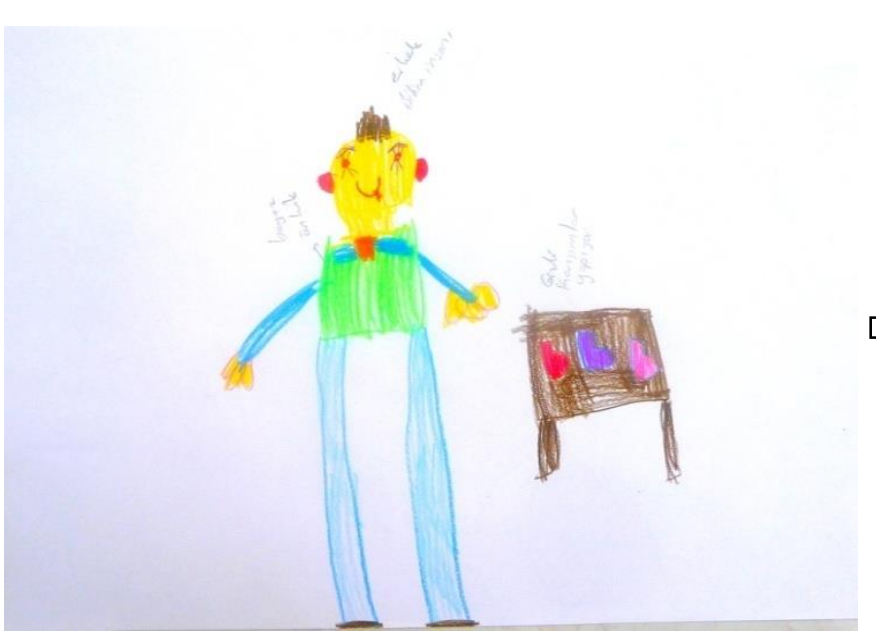

Şekil 5. Ç20 kodlu çocuğun yaptığı bilim insanı konulu resim
Ç61 kodlu çocuğun bilim insanı kavramına yönelik algısını belirlemek için ona yaptırılan resimde birden fazla ve farklı cinsiyetlerde bilim insanları bulunmaktadır. Resimdeki bilim insanları beyaz gömlek giymektedirler ve kendilerine ait kapalı bir çalışma odaları vardır. Ayrıca yapılan resimde bilgisayarlar, kamera ve masalar bulunmaktadır.

Ç20 kodlu çocuğun bilim insanı kavramına yönelik algısını belirlemek için ona yaptırılan resimde papyon takan, kısa ve az saçlı ve yalnız çalışan erkek bir bilim insanı bulunmaktadır. Ayrıca resimde bir adet masa ve masanın üzerinde üç adet laboratuvar malzemeleri yer almaktadır. Ç20'ye göre bu bilim insanı gizli karışımlar yapmaktadır.

\subsection{Okul Öncesi Çocuklarının, Bilim İnsanının Fiziksel Özellikleri Hakkındaki Algıları}

Araştırmanın bu bölümünde çocukların yaptıkları resimlerdeki bilim insanlarının fiziksel özellikleri ele alınmıştır. Yapılan resimlere göre çocukların zihinlerindeki bilim insanının fiziksel özellikleri ile ilgili veriler Tablo 4'te sunulmuştur.

Tablo 4

Çocukların Zihinlerindeki Bilim Insanının Fiziksel Özellikleri

\begin{tabular}{ccc}
\hline Fiziksel özellikler & $\mathbf{f}$ & $\%$ \\
\hline Kadın Kısa Saç & 3 & 4,4 \\
Kadın Uzun Saç & 17 & 25 \\
Erkek Uzun Saç & 6 & 8,8 \\
Erkek Kısa Saç & 21 & 30,8 \\
Erkek Saçı Yok & 20 & 29,4 \\
Bıyık & 1 & 1,4
\end{tabular}




$\begin{array}{ccc}\text { Sakal } & 3 & 4,4 \\ \text { Gözlük } & 10 & 14,7 \\ \text { Önlük } & 17 & 25 \\ \text { Eldiven } & 3 & 4,4 \\ \text { Kravat } & 3 & 4,4 \\ \text { Papyon } & 3 & 4,4 \\ \text { Şapka } & 7 & 10,2\end{array}$

Tablo 4'e göre çocukların \%4,4'ü bilim insanlarını kısa saçlı kadın, \%25'i uzun saçlı kadın, \%8,8'i uzun saçlı erkek, \%30,8'i kısa saçlı erkek, \%29,4 saçı olmayan erkek, \%1,4'ü bıyıklı, $\% 4,4$ 'ü sakallı, \%14,7'si gözlüklü, \%25'i önlüklü, \%4,4'ü eldivenli, \%4,4'ü kravatlı, \%4,4'ü papyonlu ve \%10,2'si de şapkalı olarak resmetmişlerdir. Bilim insanlarının fiziksel özelliklerine dair Ç1: "...kadın bilim adamları uzun saçı olur...", Ç40: "...bu kızın saçları kısa...", Ç42: "...bilim insanları erkektir ve uzun saçlıdır. Eldiven takarlar ve önlük giyerler...", Ç12: "...kısa saçlı bilim insanı...", Ç29: "...bilim insanı kel olur...", Ç13: "...bunun bıyıkları var...", Ç54: "...sakallı bilim adamı...", Ç55: "...bilim insanı gözlük takar...", ç61: "...profesör kıyafeti giyerler, beyaz gömlek. Yakalarında cep vardır, cebinde ışık vardır...", ç39: "...elinde eldivenleri var...", ç3: "...bilim insanı kravatlıdır...", ç9: "...papyon takan bilim insanı..." ve Ç19: "...kafalarında böyle şapka vardır..." şeklinde ifade etmişlerdir. Çocukların açıklamalarına yönelik yaptıkları resimler Şekil 6 , Şekil 7 ve Şekil 8'de sunulmuştur.
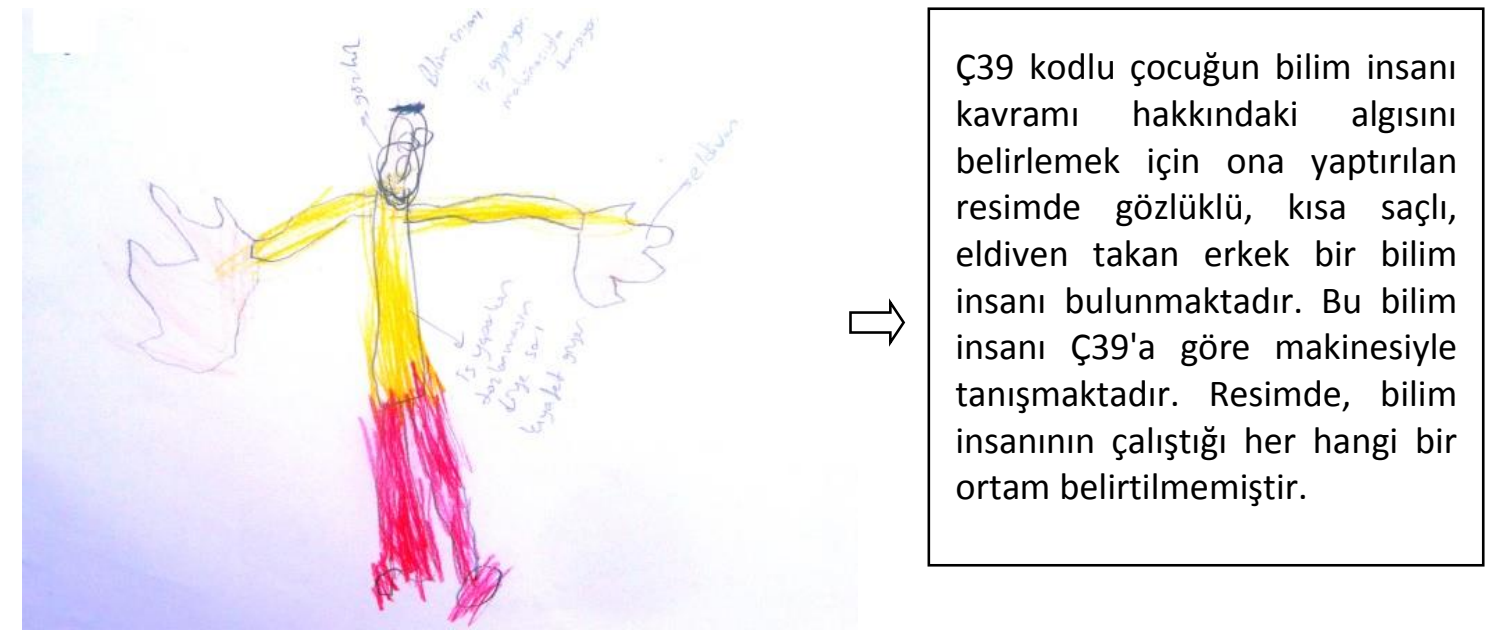

Şekil 6. Ç39 kodlu çocuğun yaptığı bilim insanı konulu resim 


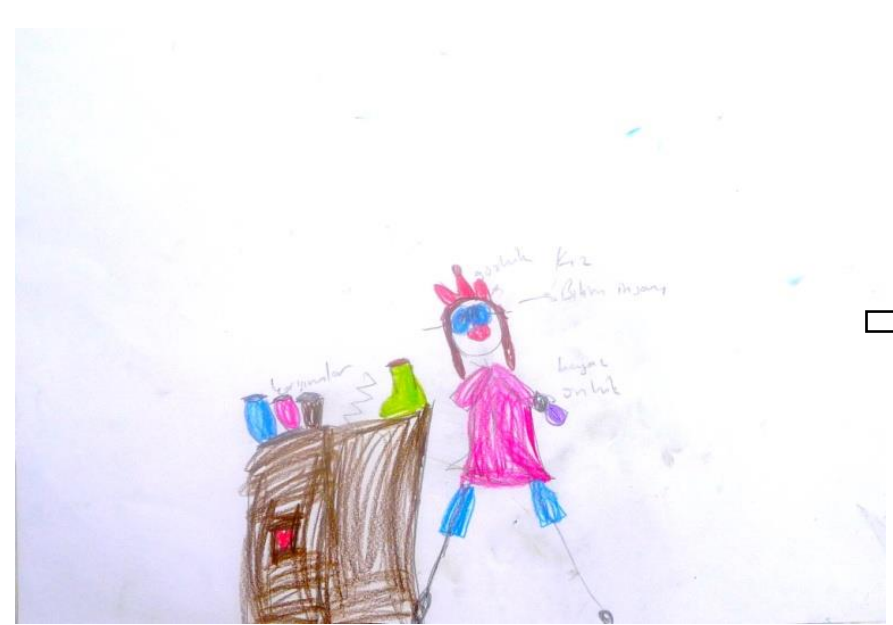

Şekil 7. Ç1 kodlu çocuğun yaptığı bilim insanı konulu resim

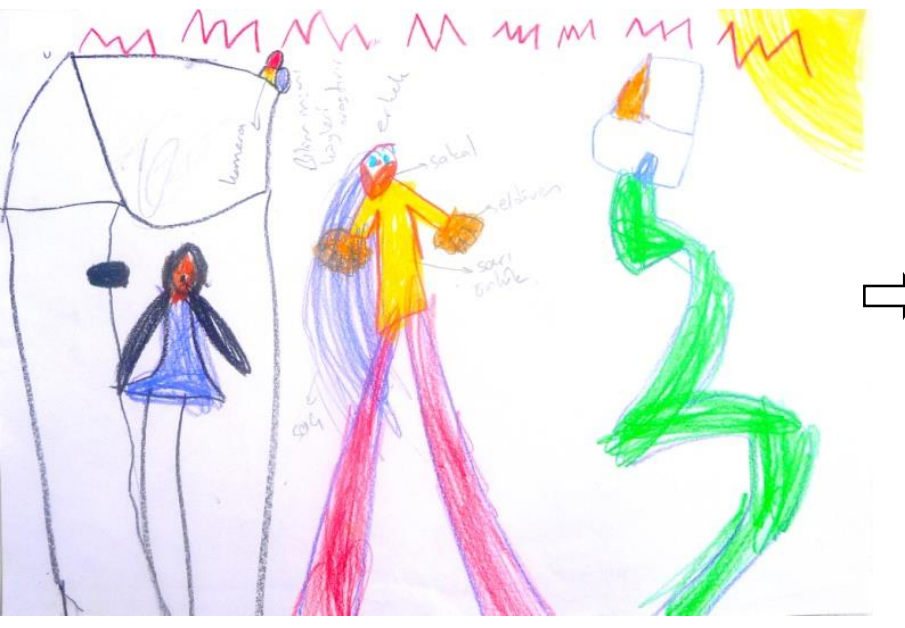

Şekil 8. Ç42 kodlu çocuğun yaptığı bilim insanı konulu resim
Ç1 kodlu çocuğun bilim insanı kavramı hakkındaki algısını belirlemek için ona yaptırılan resimde gözlüklü, önlüklü, şort giyen ve elinde büyüteç olan kadın bir bilim insanı bulunmaktadır. Ayrıca resimde bir masanın üzerinde bulunan ve içerisinde karışımların olduğu laboratuvar malzemeleri de yer almaktadır. Ç1'e göre bu bilim insanı karışımlar oluşturmaktadır.

Ç42 kodlu çocuğun bilim insanı kavramı hakkındaki algısını belirlemek için ona yaptırılan resimde sakallı, uzun saçlı, eldiven takan ve sarı önlük giyen erkek bir bilim insanı bulunmaktadır. Ayrıca resimde dağlar, güneş, evler, evin içinde yaşayan bir kadın ve evin çatısında kamera bulunmaktadır. Ç42'ye göre burası bir köydür ve resimdeki bilim insanı da köyleri araştırmaktadır.

\subsection{Okul Öncesi Çocuklarının, Bilim İnsanlarının Çalıştıkları Ortam Hakkındaki Algıları}

Araştırmanın bu bölümünde çocukların yaptıkları resimlerdeki bilim insanlarının çalıştıkları ortamları ele alınmıştır. Yapılan resimlere göre çocukların zihinlerindeki bilim insanlarının çalışma ortamlar ile ilgili veriler Tablo 5 'te verilmiştir.

Tablo 5

Çocukların Zihinlerindeki Bilim Insanlarının Çalıştıkları Ortamlar

\begin{tabular}{|c|c|c|c|c|}
\hline \multicolumn{3}{|c|}{ Ortam } & \multirow{2}{*}{$\frac{\mathbf{f}}{11}$} & \multirow{2}{*}{$\begin{array}{c}\% \\
16,1\end{array}$} \\
\hline Laboratuvar & & & & \\
\hline Sinıf & & & 1 & 1,4 \\
\hline Çalışma Odası & & & 17 & 25 \\
\hline \multirow{3}{*}{ Doğa } & Conlë̈̆̌̆lor & Bitki & 12 & 17,6 \\
\hline & 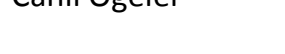 & Hayvan & 6 & 8,8 \\
\hline & Astronomik Öğeler & Yıldız & 5 & 7,3 \\
\hline
\end{tabular}




$\begin{array}{llcc} & \text { Ay } & 2 & 2,9 \\ & \text { Güneş } & 12 & 17,6 \\ \text { Doğal Oluşumlar } & \text { Bulut } & 15 & 22 \\ & \text { Gökkuşağı } & 3 & 4,4 \\ & & 27 & 39,7\end{array}$

Tablo 5'e göre çocuklar yaptıkları resimlerde bilim insanlarının çalışma ortamları konusunda \%16,1'i laboratuvarı, \%1,4'ü sınıfı, \%25'i çalışma odasını ve \%39,7'si ise belirsiz bir yeri kullanmışlardır. Bilim insanlarının çalışma ortamının doğa olduğunu belirten çocuklardan $\% 17,6$ 'sı yaptığı resimde bitki, \%8,8'i hayvan, \%7,3'ü yıldız, \%2,9'u ay, \%17,6'sı güneş, \%22'si bulut ve \%4,4'ü ise gökkuşağı modeline yer vermiştir. Bilim insanlarının çalışma ortamına dair Ç2: "...burası bir laboratuvar...", Ç11: "...burası sınıf...", Ç67: "...bilim insanı odasında çalışır..." ve Ç17: "...bilim adamı doğada yıldızları inceler..." şeklinde açıklama yapmıştır. Herhangi bir açıklama yapmayan çocuklardan bazıları bilim insanlarının çalışma ortamını kapalı bir mekân olarak resmederken bazıları ise ortam konusunda herhangi bir sınırlama getirmeyerek belirsiz bir mekanda çalışma ortamını resmetmiştir. Çocukların açıklamalarına yönelik yaptıkları resimler Şekil 9, Şekil 10 ve Şekil 11 'de sunulmuştur.

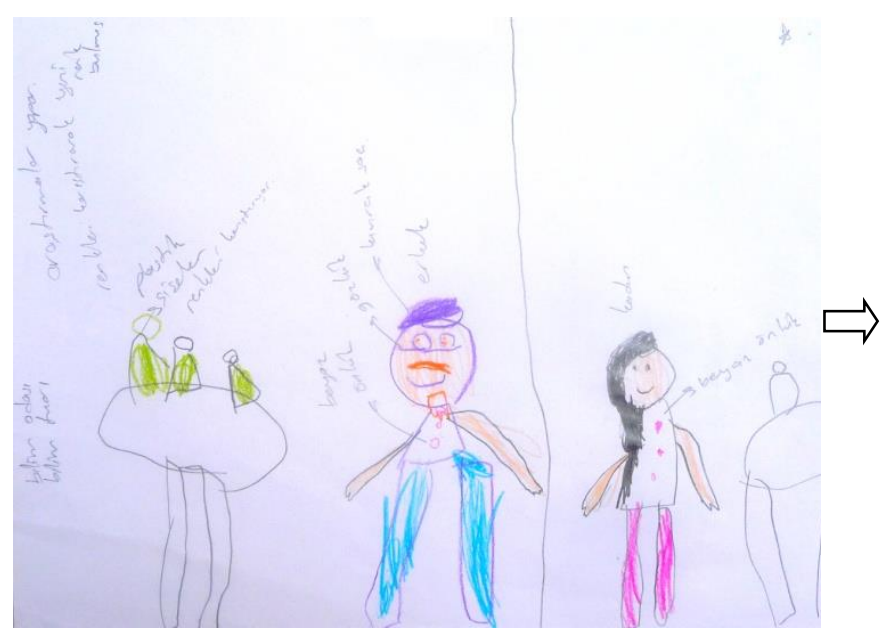

Şekil 9. Ç2 kodlu çocuğun yaptığı bilim insanı konulu resim
Ç2 kodlu çocuğun bilim insanı kavramı hakkındaki algısını belirlemek için ona yaptırılan resimde birlikte çalışan, beyaz önlük giyen, farklı cinsiyetlerde bilim insanları bulunmaktadır. Erkek bilim insanı gözlüklü, kıvırcık kısa saçlı ve papyonludur. Kadın bilim insanı ise uzun saçlı ve gözlüksüzdür. Ayrıca yapılan resimde masalar ve masaların üzerinde laboratuvar malzemeleri bulunmaktadır. Ç2'ye göre bu bilim insanları renkleri karıştırarak yeni renkler oluşturmaktadırlar.

Ç17 kodlu çocuğun bilim insanı kavramı hakkındaki algısını belirlemek için ona yaptırılan resimde birlikte çalışan iki tane uzun saçlı kadın bilim insanı bulunmaktadır. Bilim insanlarından bir tanesi gözlüklüdür. Ayrıca resimde sandalye, teleskop ve astronomik unsurlardan olan yıldızlar yer almaktadır. Ç17'ye göre bu bilim insanları teleskopla yıldızlara bakmaktadırlar. 
Şekil 10. Ç17 kodlu çocuğun yaptığı bilim insanı konulu resim

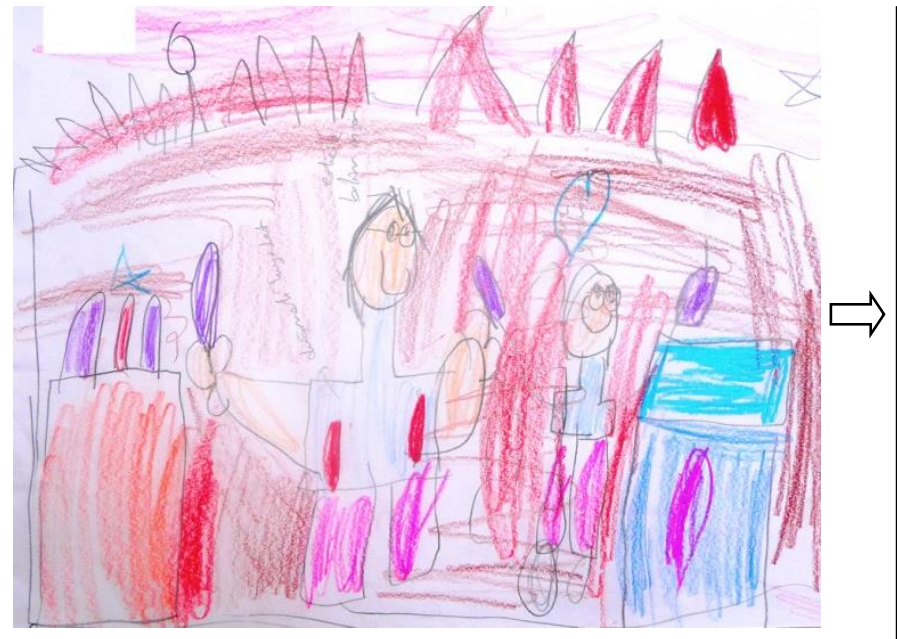

Şekil 11. Ç31 kodlu çocuğun yaptığı bilim insanı konulu resim
Ç31 kodlu çocuğun bilim insanı kavramı hakkındaki algısını belirlemek için ona yaptırılan resimde gözlük takan ve birlikte çalışan farklı cinsiyetlerde olan bilim insanları bulunmaktadır. Ayrıca resimde yıldız, masalar ve masaların üzerinde laboratuvar malzemeleri bulunmaktadır. Çalışma ortamı olarak kapalı bir mekân resmedilmiştir. Ç31'e göre bu bilim insanları düğmeli kıyafet giymektedirler.

3.5. Okul Öncesi Çocuklarının, Bilim İnsanlarının Çalışmalarında Kullandıkları Araç Gereçler Hakkındaki Algıları

Araştırmanın bu bölümünde çocukların yaptıkları resimlerdeki bilim insanlarının kullandıkları araç gereçler ele alınmıştır. Yapılan resimlere göre çocukların zihinlerindeki bilim insanlarının çalışmalarında kullandıkları araç gereçler ile ilgili veriler Tablo 6'da sunulmuştur.

Tablo 6

Çocukların Zihinlerindeki Bilim İnsanlarının Kullandıkları Araç Gereçler

\begin{tabular}{ccc}
\hline Araç Gereçler & f & \% \\
\hline Teleskop & 3 & 4,4 \\
Deney Tüpü & 6 & 8,8 \\
Mercek & 1 & 1,4 \\
Kürek & 2 & 2,9 \\
Alet Çantası & 1 & 1,4 \\
Hesap Makinesi & 1 & 1,4 \\
Saat & 1 & 1,4 \\
Lamba & 1 & 1,4 \\
Kablo & 1 & 1,4 \\
Bilgisayar & 4 & 5,8 \\
Tahta & 1 & 1,4 \\
Dolap & 1 & 1,4 \\
Makine & 1 & 1,4 \\
Masa & 10 & 14,7 \\
Kamera & 4 & 5,8 \\
\hline
\end{tabular}

Tablo 6'ya göre bilim insanlarının kullandıkları araç gereçler konusunda çocukların $\% 14,7$ 'si resimlerinde masaya, $\% 8,8$ 'i deney tüpüne, \%5,8'i kameraya, \%5,8'i bilgisayara, \%4,4'ü 
teleskopa, \%2,9'u küreğe, \%1,4'ü merceğe, \%1,4'ü alet çantasına, \%1,4'ü hesap makinesine, $\% 1,4$ 'ü saate, \%1,4'ü lambaya, \%1,4'ü kabloya, \%1,4'ü tahtaya, \%1,4'ü dolaba ve \%1,4'ü de makineye yer vermiştir. Bilim insanların kullandıkları araç gereçlere dair Ç26: "...bilim insanı odasında teleskopuyla yıldızlara bakar...", Ç43: "...elinde küreği var...", Ç7: "...bunlar masanın üstünde duran deney tüpleri. İçinde karışımlar yapar...", Ç66: "...mercekle yazıları okuyor...", Ç51: "...roketin kalkması için saatine bakarak hesap makinesinden zamanı ayarlıyor...", ç28: "...bilim adamı kablolarla lambayı yakacak...", ç1: "...bilim insanı alet çantası taşır elinde...", Ç15: "...köyü korumak için evin çatısına kamera taktı..." şeklinde ifade etmiştir. Herhangi bir açıklama yapmayan veya açıklamalarını eksik yapan çocukların resimlerinde dolap ve tahta nesnelerinin de olduğu görülmüştür. Çocukların açıklamalarına yönelik yaptıkları resimler Şekil 12 , Şekil 13 ve Şekil 14 'te sunulmuştur.

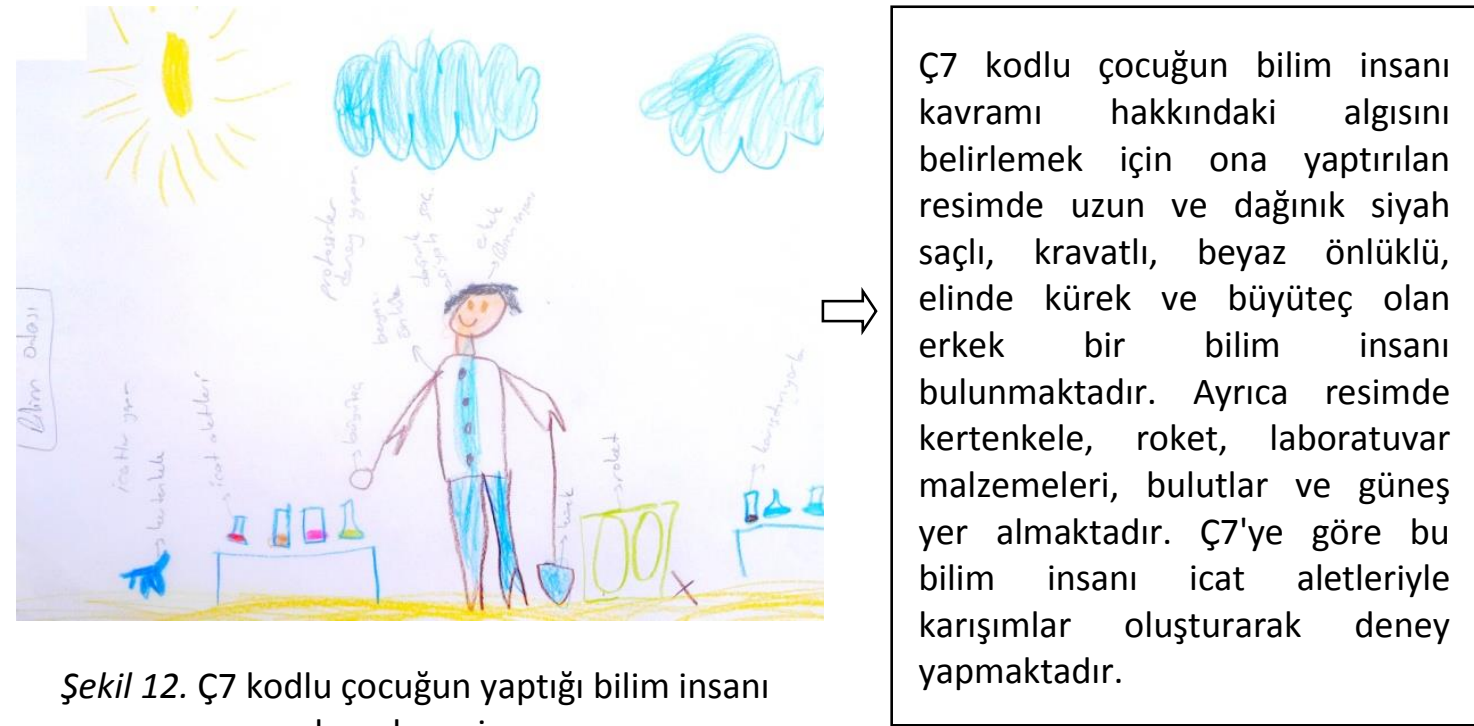
konulu resim
Ç26 kodlu çocuğun bilim insanı kavramı hakkındaki algısını belirlemek için ona yaptırılan resimde siyah ve uzun saçlı, sarı önlüklü erkek bir bilim insanı bulunmaktadır. Ayrıca resimde araba ve teleskop nesneleri yer almaktadır. Ç26'ya göre bu bilim insanı araba yapmaktadır ve teleskopla gökyüzünü incelemektedir.

Şekil 13. Ç26 kodlu çocuğun yaptığı bilim insanı konulu resim 


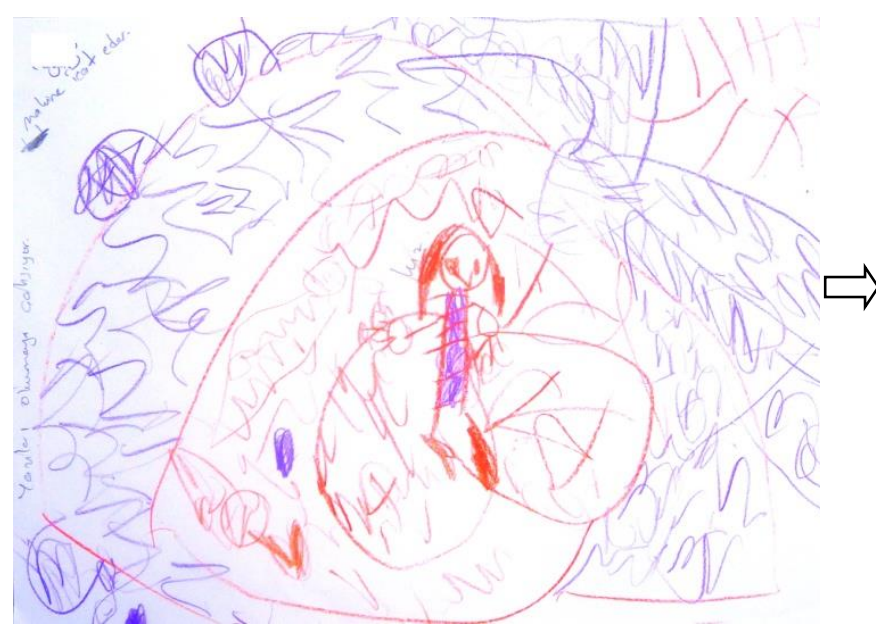

Şekil 14. Ç66 kodlu çocuğun yaptığı bilim insanı konulu resim
Ç66 kodlu çocuğun bilim insanı kavramı hakkındaki algısını belirlemek için ona yaptırılan resimde yalnız çalışan, uzun saçlı kadın bir bilim insanı bulunmaktadır. Ayrıca resimde güneş öğesine yer verilmiştir. Ç66'ya göre bu bilim insanı yazıları okumaya çalışmaktadır ve makine icat etmektedir.

\subsubsection{Okul Öncesi Çocuklarının, Bilim İnsanlarının Mesleki Özellikleri Hakkındaki Algıları}

Araştırmanın bu bölümünde çocukların yaptıkları resimlerdeki bilim insanlarının mesleki özellikleri ele alınmıştır. Yapılan resimlere göre çocukların zihinlerindeki bilim insanlarının meslekleri özellikleri ile ilgili veriler Tablo 7'de sunulmuştur.

Tablo 7

Çocukların Zihinlerindeki Bilim İnsanlarının Mesleki Özellikleri

\begin{tabular}{ccc}
\hline Mesleki Özellikler & f & $\%$ \\
\hline Deney Yapar & 2 & 2,9 \\
Tamir Eder & 1 & 1,4 \\
Makine Yapar & 3 & 4,4 \\
Robot Yapar & 10 & 14,7 \\
İcat Yapar & 8 & 11,7 \\
Gözlem Yapar & 2 & 2,9 \\
Kötülükleri Engeller & 1 & 1,4 \\
Kitap Okur & 1 & 1,4 \\
Hesap Yapar & 1 & 1,4 \\
Roket Yapar & 2 & 2,9 \\
Karışımlar Oluşturur & 5 & 7,3 \\
Araştırma Yapar & 5 & 7,3 \\
Düşünür & 2 & 2,9
\end{tabular}

Tablo 7'ye göre bilim insanlarının ne iş yaptığı konusunda çocukların \%14,7'si robot yaptığını, \%11,7'si icat yaptığını, \%7,3'ü karışımlar oluşturduğunu, \%7,3'ü araştırmalar yaptığını, \%4,4'ü makine yaptığını, \%2,9'u deney yaptığını, \%2,9'u gözlem yaptığını, \%2,9'u roket yaptığını, \%2,9'u düşündüğünü, \%1,4'ü tamir ettiğini, \%1,4'ü kötülükleri engellediğini, \%1,4'ü kitap okuduğunu ve \%1,4'ü de hesap yaptığını ifade etmiştir. Bilim insanlarının mesleki özelliklerine dair çocuklardan Ç18: "Bilim insanları robot yapar.", Ç25: "...icat yapar...", Ç7: 
"...yeni şeyler bulmak için karışımlar yaparlar...", ç9: "...bilim insanı bazı şeyler araştırır...", Ç68: "...makine yaparlar...", Ç44: "...bilim adamı deneylerle uğraşır...", Ç41: "...gözlem yaparlar...", Ç34: "...bilim insanı roket yapıp uçurur...", Ç51: "...bilim insanı uzanmış düşünüyor...", Ç53: "...bozulan makineleri tamir eder...", Ç19: "...bilim adamları bizi kötülüklerden korur...", Ç3: "...bilim insanları çok kitap okurlar..." ve ç8: "...bilim insanı hesap yapıyor..." şeklinde ifade etmiştir. Çocukların açıklamalarına yönelik yaptıkları resimler Şekil 15, Şekil 16 ve Şekil 17'de sunulmuştur.

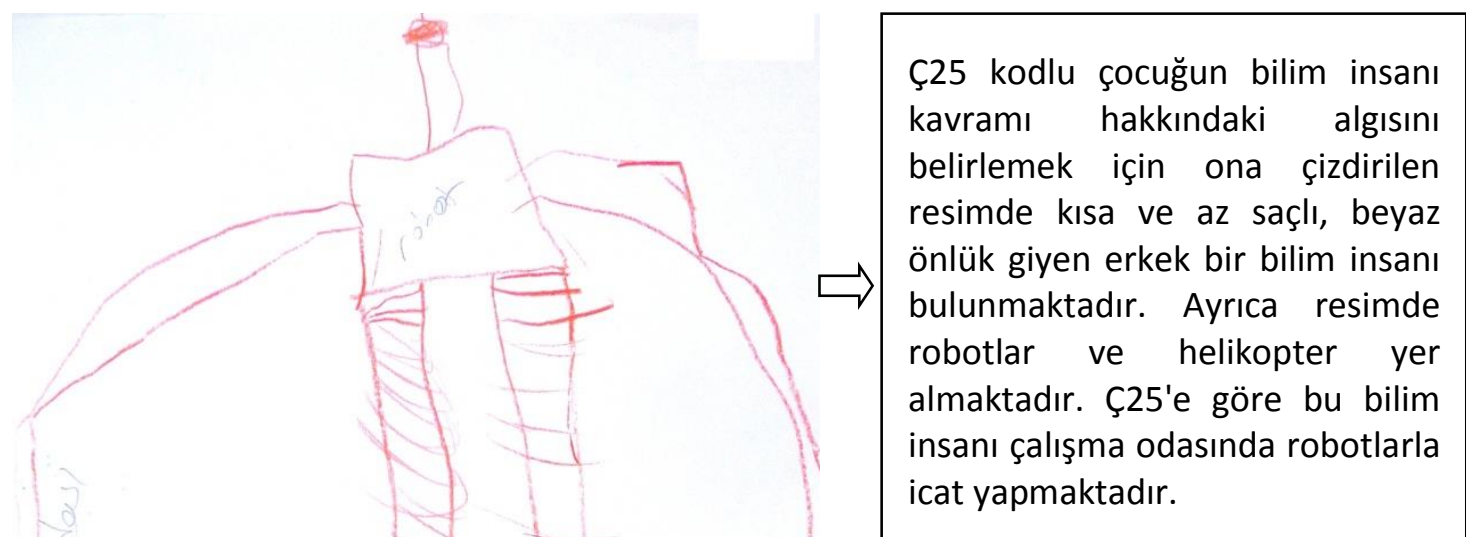

Şekil 15. Ç25 kodlu çocuğun yaptığı bilim insanı konulu resim 


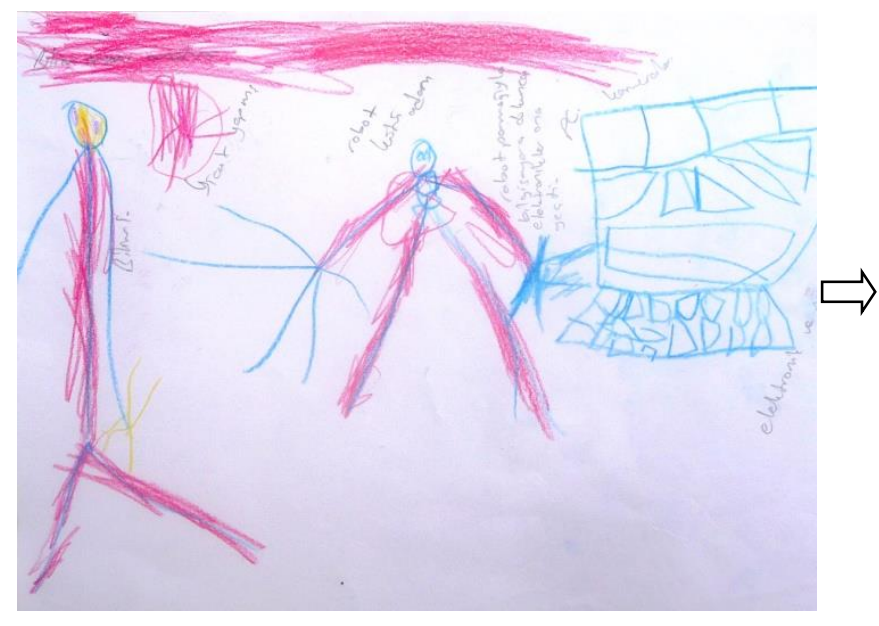

Ç18 kodlu çocuğun bilim insanı kavramı hakkındaki algısını belirlemek için ona yaptırılan resimde saçı olmayan erkek bir bilim insanı bulunmaktadır. Ayrıca resimde robot, bilgisayar ve kameralar yer almaktadır. Ç18'e göre bu bilim insanı robot icat etmiştir.

Şekil 16. Ç18 kodlu çocuğun yaptığı bilim insanı konulu resim

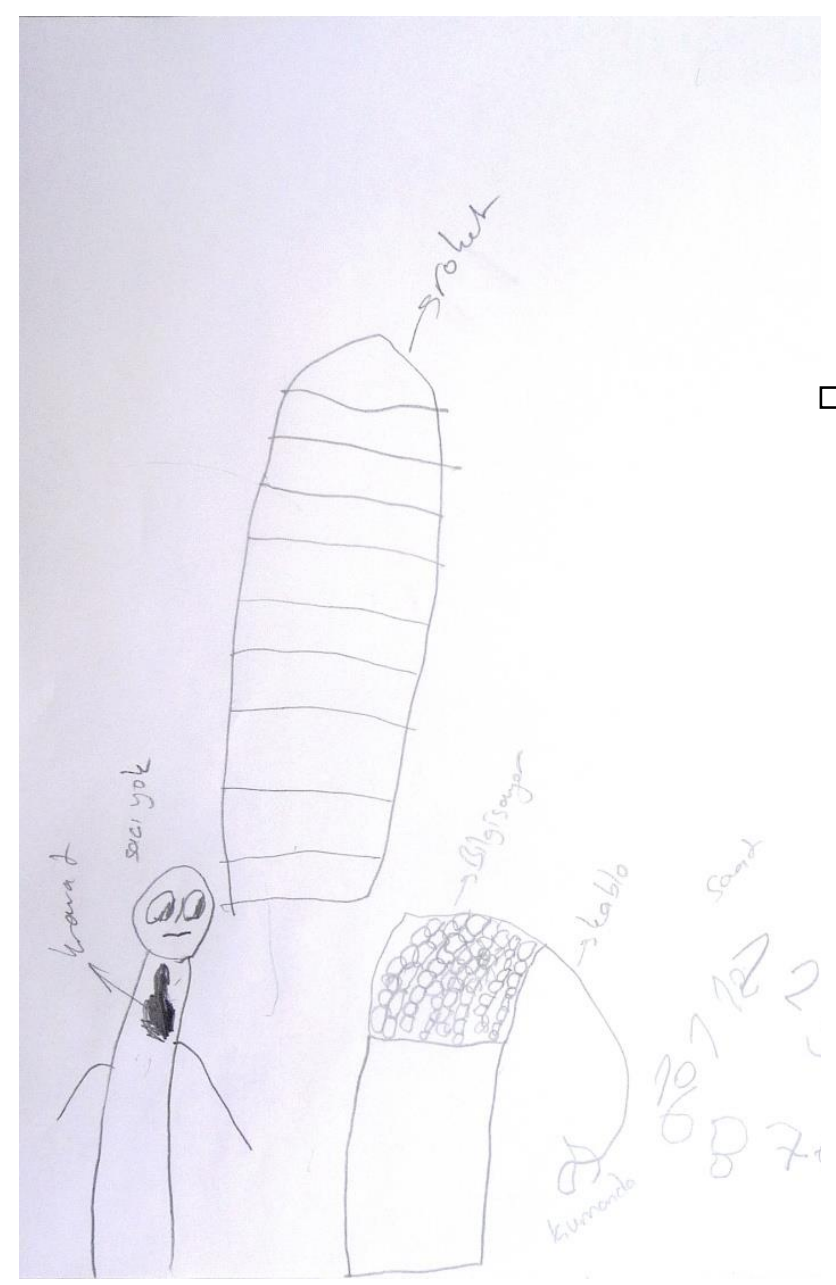

Ç34 kodlu çocuğun bilim insanı kavramı hakkındaki algısını belirlemek için ona yaptırılan resimde saçı olmayan, kravat takan ve diğer kıyafetleri konusunda herhangi bir bilgi bulunmayan erkek bir bilim insanı bulunmaktadır. Ayrıca resimde roket, bilgisayar, kablo, kumanda, masa ve saat nesnelerine yer verilmiştir. Ç34'e göre bu bilim insanı roket yapmıştır ve roketi uzaya göndermektedir.

Şekil 17. Ç34 kodlu çocuğun yaptığı bilim insanı konulu resim 


\section{TARTIŞMA VE SONUÇ}

Okul öncesi çocuklarının bilim insanı kavramına yönelik algılarının belirlendiği bu çalışmada çocukların bilim insanına yönelik yaptıkları resimler fiziksel özellikler, cinsiyet, çalışma şekli, çalışma ortamı, kullanılan araç gereçler ve mesleki özellikler açısından değerlendirilmiştir. Öğrencilerin bilim insanı hakkındaki düşünceleri ile ilgili literatür araştırılığında farklı ülkelerde ve eğitimin farklı kademelerinde bulunan öğrencilerin bilim insanı hakkındaki düşüncelerini belirlemeye yönelik çeşitli çalışmalara rastlanmaktadır. Okul öncesi çocuklarına (Güler ve Akman, 2003), ilkokul ve ortaokul öğrencilerine (Balkı, Çoban ve Aktaş, 2003; Buldu, 2006; Chambers, 1983; Deniş Çeliker ve Erduran Avcı, 2015; Fralick, Kearn, Thompson \& Lyons, 2009; Kaya, Doğan ve Öcal, 2008; Kara ve Akarsu, 2013; Kılıç, 2010; Küçük ve Bağ, 2011; Medina, Kyndra \& Orihuela, 2011; Monhardt, 2003; Nuhoğlu ve Afacan, 2007; Özsoy ve Ahi, 2014; Painter \& Tretter, 2006; Schibeci \& Sorensen, 1983; Symington \& Spurling, 1990; Şahin, 2009; Thomas \& Hairston, 2003), orta öğretim öğrencilerine (Doğan Bora, Arslan ve Çakıroğlu, 2006; Mason, Kahle \& Gardner, 1991), üniversite öğrencilerine (Bovina \& Dragul'Skaia, 2008) ve öğretmen adaylarına (Demirbaş, 2009; Moseley \& Norris, 1999; Şenel \& Aslan, 2014) yönelik bilim insanı ile ilgili düşüncelerine ilişkin çalışmalar mevcuttur. Yapılan bu çalışmada ise okul öncesi çağındaki $48-72$ ay aralığında bulunan çocukların bilim insanına yönelik algılarına yer verilmiştir.

Chambers'ın "Bir Bilim Insanı Çiz Testi" kullanılarak derinlemesine mülakat yöntemi ile yürütülen bu çalışma, okul öncesi çağında bulunan 68 çocuğa, bilim insanı kavramına yönelik algılarını belirlemek amacıyla uygulanmıştır. Uygulama sırasında çocuklara bilim insanı ile ilgili resim yaptırılmış ve ardından yaptıkları resimleri açıklamaları amacıyla onlara bilim insanının nerede olduğu, nerede çalıştığı, neler kullandığı, nasıl göründüğü gibi çeşitli sorular sorularak mülakatlar yapılmıştır. Bu çalışmada resim yeteneği olmayan veya yaptığı resim anlaşılmayan çocukların verileri ile onlarla yapılan derinlemesine mülakatlardan elde edilen veriler karşılaştırılarak değerlendirme yapılmıştır. Benzer şekilde Nuhoğlu ve Afacan'ın (2007) yaptığı çalışmada da öğrencilere bilim insanı ile ilgili yaptırılan resimlere ilave olarak onlar hakkındaki bilgiler açık uçlu sorularla değerlendirilmiştir.

Yapılan uygulama sonucunda çocuklardan \%66,17'si bilim insanını erkek, \%22,05'i kadın ve \%11,76'sı ise yaptıkları resimlerinde hem kadın hem de erkek bilim insanına yer vermiştir. Elde edilen bu sonuçlar ile daha önceden bu konuda yapılan çalışmalar karşılaştırıldığında bilim insanının cinsiyeti ile ilgili Nuhoğlu ve Afacan'ın (2007) yaptığı araştırmadaki öğrencilerin \%60'ı bilim insanını erkek, \%23'ü ise kadın olarak resmetmiştir. Benzer şekilde Chambers'ın (1983) yaptığı araştırmada 4.807 öğrenciden sadece 28 tanesi resimlerinde bilim insanını kadın olarak yapmıştır. Kaya, Doğan ve Öcal'ın (2008) yaptığı çalışmada öğrencilerin \%78'inin yaptıkları resimlerdeki bilim insanını erkektir. Ayrıca Korkmaz ve Kavak'ın (2010) ve Yontar Toğrol'un (2000) çalışmalarının sonuçları da benzer niteliktedir. Bu konuda daha önceden yapılan çalışmalar araştırıldığında, erkek ve kadın bilim insanı çizimlerinin aynı resimde yer aldığı gözlemlenmemiştir. Bu çalışmanın yapıılığı yer ve zaman dikkate alındığında bir işi yapan her iki cinsiyetten insanın da olduğu algısı artık yavaş yavaş Türk toplumunun her kesimine yayılmaya başlamıştır. Buradan, zamanla kadın ve erkek bilim insanlarının da olabildiği ve birlikte çalışabildikleri fikrinin yapılanmaya başladığı anlaşılmaktadır. Bu yapılanmanın teknolojik gelişmeler, filmler, çizgi filmler, çocuk kitapları gibi etkenler sayesinde olduğu düşünülmektedir. Teknolojinin hayatımıza hışımla girdiği ve bizim düşüncelerimizi değiştirdiği hatta şekillendirdiği günümüzde bu durum gayet anlaşılır bir süreçtir. Ayrıca bazı çocuklar resimlerin açıklamasını yaparken yaptıkları kadın bilim insanı için kadın bilim adamı kavramını kullanmışlardır. Bu da bize "bilim insanı" kavramının toplumda tam olarak benimsenmediğini göstermektedir. 
Örnekleme katılan okul öncesi çocuklarının yaptıkları resimlere bakıldı̆ıında genel olarak çocuklar resimlerinde bir tane bilim insanına yer vererek bilim insanlarının yalnız çalıştıklarını belirtmişlerdir. Ayrıca çocukların yaptıkları resimlerden ve yapılan mülakatlardan elde edilen verilere göre çocuklar, bilim insanının çoğunlukla kendisine ait bir çalışma odasında veya laboratuvarda çalıştığını düşündükleri sonucuna varıımıştır. Bu sonuçları doğrular nitelikte Deniş Çeliker ve Erduran Avcı'nın (2015) çalışmasındaki ilkokul öğrencilerine yapılan testte öğrencilerden \%56,2'si bilim insanının bireysel çalıştığını belirtmekle beraber Nuhoğlu ve Afacan'ın (2007) yaptığı çalışmada da öğrencilerin \%40'ının, bilim insanının çalışma yeri olarak laboratuvarı belirttikleri görülmüştür. Toplumsal olarak bilim ve bilimsel bilginin, özel donanımlara sahip olan ortamlarda üretilebildiği fikri kısmen doğru olmasına rağmen her yerin bir laboratuvar olduğu gerçeği öğrenciler, hatta toplum tarafından göz ardı edilmektedir. Örneğin orman morfolojisi çalışan bir bilim insanının laboratuvarı bir orman, uzay fiziği çalışan bir bilim insanının laboratuvarı ise tüm evrendir. Bu durumda öğrenciler okul öncesi çağlardan başlayarak bilimin ve bilimsel bilginin üretildiği yeri kısıtlı şekilde algıladıkları görülmektedir.

Bu çalışmadaki okul öncesi çocuklarına göre bilim insanları genellikle robot yapan, icat yapan, araştırmalar yapan ve karışımlar oluşturan; kısa saçlı veya saçsız, önlük giyen ve gözlük takan kişilerdir. Bu algı, okul öncesi çocuklarına bilim insanı denildiğinde Einstein'ın meşhur görüntüsünün zihinlerinde canlanmasına sebebiyet vermektedir. Einstein'ın bu görüntüsü birçok çizgi filmde karikatürlerde resimli kitaplarda hatta reklamlarda oldukça sık kullanılmaktadır. Barrett ve Braham'ın (1995) yaptıkları araştırmaya göre medya, çocukların algı, tutum, değer, duygu, beklenti ve davranışlarında yoğun olarak şekillendirici ve belirleyici bir etkiye sahiptir. Ayrıca Şahin'in (2009) ilköğretim birinci kademe öğrencileri ile bilim insanına yönelik yaptığı çalışma sonuçlarına bakıldığında, bilim insanları icat ve buluş yapan kimseler olduğu görülmektedir. Güler ve Akman'ın (2006) araştırmalarında, çocukların bilim insanının fiziksel özellikleri ile ilgili verdikleri cevaplar arasında; önlük, gözlük ve dağınık uzun saç yer aldığı görülmüştür.

Resimler, bilim insanlarının kullandığı araç gereçler açısından incelendiğinde çoğunlukla deney tüpü gibi laboratuvar malzemeleri, teleskop, kamera ve bilgisayara rastlanmıştır. Ayrıca resimlerde yer alan diğer eşyalar arasında masa, dolap ve sandalye de yer almaktadır. Nuhoğlu ve Afacan (2007), öğrencilerin araç gereç olarak çoğunlukla deney tüpü resmettiklerini, odayı dolduran diğer eşyaların da çoğunlukla laboratuvar malzemelerinin konulduğu dolap, masa ve kütüphane olduğunu ifade etmişlerdir. Bu çalışmadaki bazı resimlerde yer alan kamera öğesi için araştırma yapıldığında literatürde her hangi bir sonuca rastlanmamıştır. Bunun sebebi olarak da ilerleyen teknoloji sayesinde geliştirilen ürünlerin günlük hayatımızda daha fazla kullanılması ve bu sayede çocukların zihinlerinde yer alması gösterilebilir.

Bazı çocuklardan bilim insanı ile ilgili herhangi bir bilginin alınamamasını, bulundukları bilişsel gelişim dönemiyle açıklamak mümkündür. Çünkü 48-72 ay aralığındaki çocuklar duyu organlarını kullanarak bilgi edinmektedirler (Ayvacı, 2010) ve tanımlamalarını da duyu organları ile algılayabildikleri kadar yapabilmektedirler. Bundan dolayı bu konuda yapılan araştırmalara göre 48-72 ay grubu çocuklarının bilim ve bilim insanı ile ilgili bilgilerinin sınırlı olduğu söylenebilir (Güler ve Akman, 2006).

\section{5. ÖNERILER}

Araştırmalardan elde edilen sonuçlar doğrultusunda okul öncesi eğitimde çocuklara bilim insanı ile ilgili daha gerçekçi algılar oluşturmak amacıyla bilim insanı konulu etkinliklere daha fazla yer verilmelidir. Bu etkinlikler, çocukların bilimsel çalışmalar yapan bir bilim insanı gibi hissetmelerine olanak tanıyacak türden olmalıdır. Çocuklara somut yaşantılar sağlanarak onların zihinlerinde oluşacak olan bilim insanı modellerini en gerçekçi şekilde oluşturmalarına 
imkân verilmelidir. Bu bağlamda okula farklı cinsiyetlerde bilim insanları davet edilerek çocuklara meslek tanıtımı da yapılmalıdır. Ayrıca laboratuvar gezileri düzenlenip bir bilim insanı eşliğinde orada küçük deneyler yaptırılarak çocukların bir bilim insanını, fiziksel özelliklerini, kullandığı araç gereçleri ve yaptığı çalışmaları somut bir şekilde görmeleri sağlandıktan sonra zihinlerinde gerçekçi bir bilim insanı modeli oluşturmalarına olanak tanınmalıdır.

Kişilerde bilim ve bilim insanı ile ilgili algılar okul öncesi dönemlerden itibaren oluşmaya başladığından, bu dönemde yapılacak olan çalışmalar kişinin ileride bilim insanına yönelik algıların oluşmasında etkili olacağı unutulmamalıdır. Bu nedenle formal eğitimde okul öncesinden itibaren bilim, bilim insanı ve bilimsel bilginin yapısı gibi kavramlar öğrencilerin zihinlerinde doğru yapılandırılmalıdır.

Okul öncesi çağlardan itibaren bilim ve bilimsel bilginin üretilme şekillerini doğru şekilde algılayacak yönde etkinlikler yürütülmelidir. Laboratuvarın sınırları duvarlarla çevrilmiş, içinde özel donanımlar bulunan yerlerin de dışında olabileceği vurgusu öğrencilere benimsetilmelidir.

\section{KAYNAKLAR}

Ayvacı, H. Ş. (2010). Okul öncesi dönem çocuklarının bilimsel süreç becerilerini kullanma yeterliliklerini geliştirmeye yönelik pilot bir çalışma. Necatibey Eğitim Fakültesi Elektronik Fen ve Matematik Eğitimi Dergisi (EFMED). 4(2), 1-24.

Aslan, O., Yalçın, N. \& Taşar, M. F. (2009). Fen ve teknoloji öğretmenlerinin bilimin doğası hakkındaki görüşleri. Ahi Evran Üniversitesi Eğitim Fakültesi Dergisi, 10(3), 1-8.

Balkı, N., Çoban, A. K. \& Aktaş, M. (2003). İlköğretim öğrencilerinin bilim ve bilim insanına yönelik düşünceleri. Uludağ Üniversitesi Eğitim Fakültesi Dergisi, 17(1), 11-17.

Barman, C. R. (1997). Students' wievs of scientists and science: results from a national study. Science and Children. 35(1), 18-24.

Barrett, O. \& Braham, P. (1995). Media, knowledge and power, London: Routledge.

Bovina, I. B. \& Dragul'Skaia, I. U. (2008). College students' representations of science and the scientist. Russian Education and Society, 50(1), 44-64.

Buldu, M. (2006). Young children's perceptions of scientists: A preliminary study. Educational Research, 48(1), 121-132.

Chambers, W. D. (1983). Stereotypic images of scientist: The draw-ascientist test. Science Education. 67(2): 255-265.

Creswell, J. W. (2002). Educational research: planning, conducting, and evaluating quantitative and, qualitative research. Upper Saddle Creek, NJ: Pearson Education.

Çepni, S. (2008). Fen ve teknoloji öğretimi (7.Baskı), Ankara: Pegem Akademi.

Çepni, S. (2010). Araştırma ve proje çalışmalarına giriş (5.Baskı), Trabzon: Ofset Matbaacılık.

Çermik, H. (2013). Öğretmen adaylarının zihinlerinde canlanan resimdeki bilim insanı. Pamukkale Üniversitesi Eğitim Fakültesi Dergisi. 33, 139-153.

Demirbaş, M. (2009). The relationships between the scientist perception and scientific attitudes of science teacher candidates in Turkey: A case study. Scientific Research and Essay, 4(6), 565-576. 
Deniş Çeliker, H. \& Erduran Avcı, D. (2015). Ilkokul öğrencilerinin bilim insanı algıları: öğrencilerin bilimsel faaliyetlere katılması bilim insanı algılarını nasıl etkiler? Mehmet Akif Ersoy Üniversitesi Eğitim Fakültesi Dergisi. 36, 90-104.

Doğan Bora, N., Arslan, O. \& Çakıroğlu, J. (2006). Lise öğrencilerinin bilim ve bilim insanı hakkındaki görüşleri. Hacettepe Üniversitesi Eğitim Fakültesi Dergisi. 31, 32-44.

Ekiz, D. (2009). Bilimsel araştırma yöntemleri. Ankara: Anı Yayıncılık.

Fralick, B., Kearn, J., Thompson, S. \& Lyons, J. (2009). How middle schoolers draw engineers and scientists. Journal of Science Education \& Technology, 18(1), 60-73.

Güler, T. \& Akman, B. (2006). 6 yaş çocuklarının bilim ve bilim insanı hakkındaki görüşleri. Hacettepe Üniversitesi Eğitim Fakültesi Dergisi. 31, 55-56.

Johnson J. M. (2002). In-depth interviewing. Handbook of interview research: Context and method, Sage Publications. London.

Kara \& Akarsu (2013). Ortaokul Öğrencilerinin Bilim İnsanına Yönelik Tutum ve İmajının Belirlenmesi. Journal of European Education. 3(1).

Kaya, O. N., Doğan, A. \& Öcal, E. (2008). Turkish elementary school students'images of scientists. Eurasian Journal of Educational Research. 32, 83-100.

Kılıç, Ş. (2010). Çocukların bilime ve bilim insanına yönelik tutumları ve kalıplaşmış yargıları. Türk Eğitim Bilimleri Dergisi, 8(2), 439-455.

Korkmaz, H. (2004). Fen ve teknoloji eğitiminde alternatif değerlendirme yaklaşımları, Ankara: Yeryüzü Yayınevi.

Korkmaz, H. \& Kavak, G. (2010). İlköğretim öğrencilerinin bilime ve bilim insanına yönelik imajları. Ilköğretim Online. 9(3), 1055-1079.

Küçük, M. \& Bağ, H. (2011). 4 ve 5. sınıf öğrencilerinin bilim insanı imajlarının karşılaştırılması. Bayburt Üniversitesi Eğitim Fakültesi Dergisi. 7(2).

Mason, C. L., Kahle, J. B. \& Gardner, A. L. (1991). Draw-a-scientist test: future implications. School Science and Mathematics, 91(5), 193-198.

McCracken G. (1988). The long interview, Sage Publications, London.

Medina-Jerez, W., Kyndra V. M. \& Orihuela-Rabaza, W. (2011). Using the dast-c to explore colombian and Bolivian students' images of scientists. International Journal of Science and Mathematics Education, 9(3), 657-690.

Merriam, S. (1998). Qualitative researchand case study applications in education. San Francisco: Jossey-Bass.

Monhardt, R. M. (2003). The image of the scientist through the eyes of Navajo children. Journal of American Indian Education, 42(3), 25-39.

Moseley, C. \& Norris, D. (1999). Preservice teachers' views of scientists. Science and Children, 37(1), 50-56.

Nuhoğlu, H. \& Afacan, Ö. (2011). İlköğretim öğrencilerinin bilim insanına yönelik düşüncelerinin değerlendirilmesi. 16. Ulusal Eğitim Bilimleri Kongresi. 05 - 07 Eylül 2007, Tokat.

Özgelen, S. (2012). Turkish young children's views on science and scientists. Educational Sciences: Theory \& Practice - Special Issue, 3211-3225. 
Özoğlu, Ç. (1994). Bilim ve eğitim ilişkileri. Türkiye Bilimler Akademisi -Bilimsel Toplantı Serileri2, 2-3 Aralık 1994 (s. 75-83). Ankara:TÜBA.

Özsoy, S. \& Ahi, B. (2014). Çocukların Gözüyle "Bilim İnsanı". Necatibey Eğitim Fakültesi Elektronik Fen ve Matematik Dergisi (EFMED), 8(1), 204-230.

Painter, P. \& Tretter, T. R. (2006). Pulling back the curtain: uncovering and changing students'perceptions of scientists, School Science and Mathematics, 106(4), 181-190.

Schibeci, R. A. \& Sorensen, I. (1983). Elementary school children's perceptions of scientists, School Science And Mathematics, 83(1), 14-20.

Symington, D. \& Spurling, H. (1990). The draw a scientist test: interpreting the data. Research in Science and Technological Education, 8(1), 75-77.

Şahin, D. (2009). İlköğretim birinci kademe öğrencilerinin bilim insanına yönelik düşünceleri. http://www.eab.org.tr/eab/2009/pdf/284.pdf (Erişim Tarihi: 2016, 28 Mayıs).

Şenel, T \& Aslan, O. (2014). Okul öncesi öğretmen adaylarının bilim ve bilim insanı kavramlarına ilişkin metaforik algıları. Mersin Üniversitesi Eğitim Fakültesi Dergisi, 10(2), 76-95.

Tatlı, E., Önen, F., Akgül, E. M. \& Gürdal, A. (2013). Fen bilgisi öğretmenlerinin bilim ve bilim insanı algıları. 4th International Conference on New Horizons in Education (June 25-27) Rome, Italy.

Tekin, H. H. (2012). Nitel araştırma yönteminin bir veri toplama tekniği olarak derinlemesine görüşme. Sosyoloji Dergisi. 3(13), 101-116.

Thomas, J., \& Hairston, R., (2003). Adolescent students' images of an environmental scientist: an opportunity for constructivist teaching. Electronic Journal of Science Education, 7(4), $1-25$.

Yıldırım, C. (2005). Bilimin öncüleri. Ankara: Tübitak Popüler Bilim Kitapları.

Yıldırım, A. \& Şimşek, H. (2008). Sosyal bilimlerde nitel araştırma yöntemleri (7. Baskı), Ankara: Seçkin Yayıncılık.

Yontar Toğrol, A. (2000). Öğrencilerin bilim insanı ile ilgili imgeleri. Eğitim ve Bilim, 25(118), 4957. 


\section{SUMMARY}

In today's world, where scientific applications are needed and the products developed from these applications are used in any field, the importance of science is an indisputable fact. When science is considered as a study that emphasizes critical and logical thinking, wondering and suspicion, scientist can be regarded as people who start this work, conduct it and terminate it in the best way. When examining the studies for the concepts of science and scientists it is understood that these concepts begin to come into existence in the pre-school period. Children encounter with the concepts of science and scientists when they try to recognize and make sense of their environment at an early age and they constitute their certain judgments in this period. Children, during this period, can shape the concept of science purely and simply through role models and they enter the process of creating a perception of science. In this case, ascertainment of how pre-school children perceive the concept of science can only be understood by way of how they perceive the scientists, the representatives of science. Because the perception about scientists begins to form at an early age, pre-school children need to study more on perceptions about scientists. In this work, perceptions of children to the concept of scientists in the changing world have been tried to be determined.

This research is qualitatively designed in order to reveal pre-school children's perceptions of scientists. In this descriptive study, special case method, which offers the opportunity to study in-depth detail on the problems of research, was used. In the study, pre-school students' perceptions about the scientist were obtained through drawings and unprejudiced perception formed by participants with their own experiences has been tried to be revealed. The participants of the study constitute 68 children in the range of 48-72 months, studying at two randomly selected kindergartens in Beşikdüzü, Trabzon. With the purpose of revealing children's perceptions about the concept of scientist, depth interview technique was applied by using Chamber's (1983) "Draw a Scientist Test" as a data collection tool. In the test, children were asked to draw a scientist, engaged in scientific research, on a blank paper given to them and explain their paintings. Any restrictions about the choice of crayons to use in their drawings were not placed to children and there was no guidance on what they draw during this process. The data obtained from inquiries were noted and analyzing of the drawings started. In the analysis of drawings made by children, common codes and themes were tried to be determined by using the Triangulation research and also referring to the expert opinion. According to the results of analysis, most pre-school childrenindicated the scientists as people, who are male, short-haired or hairless, wearing apron and glasses, working individually in his own workroom or laboratory, using telescopes, computers, test tubes, and camera, making robots and invents, creating mixtures, making researches, machines, experiments and observations.

Considering the time and place of this study, it has been slowly observed that perception of the people of both sexes being exist spread to all segments of Turkish society. It is understood that, from this point of view, the idea that female and male scientists can exist and they can work together start to reconstruct. It is considered that this reconstruction is by means of factors such as technological developments, movies, cartoons, children's books. This situation is a pretty straightforward process at the present time which technology enters furiously into our lives and changes, even shapes our thoughts. Besides, while they were making explanations about their paintings, some children used the term "women scientists" for female scientists they drew. This shows us that the term "scientist" is not fully adopted in the society.

Although the idea that science and scientific knowledge can be produced in an environment with specific hardware is socially partly true, the fact that each space is a laboratory is ignored by students, even by society. In this case, it is seen that students perceive the science and the place where scientific knowledge is produced in a limited way starting from the pre-school age.

Based on the results obtained from research, activities about scientist should be given more places in order to create a more realistic perception about scientists at pre-school education term. These activities should allow children to feel like a scientist engaged in scientific studies. By providing concrete experiences, the opportunity to create perception of scientists in the most realistic way in their minds should be given to children. In this context profession presentation must be prepared for children by inviting scientists in different genders to the school. In addition, laboratory trips should be arranged. Performing small experiments accompanied by a scientist, children should be provided to see a scientist, his/her physical characteristics, the tools he/she used and his/her work in a concrete way. Moreover, the emphasis that a laboratory can also be somewhere except the areas with special equipment and surrounded by walls should be adopted to students. 